\title{
Psoralidin inhibits proliferation and enhances apoptosis of human esophageal carcinoma cells via NF-кB and PI3K/Akt signaling pathways
}

\author{
ZHILIANG JIN $^{1 *}$, WEI YAN ${ }^{2 *}$, HUI JIN $^{3}$, CHANGZHENG GE ${ }^{1}$ and YANHUA XU ${ }^{1}$ \\ Departments of ${ }^{1}$ Oncology, ${ }^{2}$ Gastroenterology and ${ }^{3}$ Neonatology, Jingzhou Central Hospital, \\ Jingzhou, Hubei 434020, P.R. China
}

Received December 2, 2014; Accepted December 18, 2015

DOI: $10.3892 / \mathrm{ol} .2016 .4716$

\begin{abstract}
Esophageal cancer is the most common gastrointestinal cancer. Psoralidin exhibits antioxidant, anti-apoptotic, anti-inflammatory and antitumor effects, which result in the inhibition of cancer formation. The present study aimed to investigate the effect of psoralidin on esophageal carcinoma proliferation and growth, and to elucidate its underlying mechanism of action. The effect of psoralidin on cell proliferation was investigated using 3-(4,5-dimethylthiazol-2-yl)-2,5-diphenyltetrazolium bromide assay. Using an annexin V-fluorescein isothiocyanate/propidium iodide apoptosis detection kit and 4',6-diamidino-2-phenylindole staining assay, the present study demonstrated that psoralidin significantly enhanced apoptosis of human esophageal carcinoma Eca9706 cells. In addition, caspase- 3 activity was analyzed with a caspase- 3 colorimetric assay kit, while nuclear factor (NF)- $\kappa \mathrm{B}$ activity and protein phosphatidylinositol 3-kinase (PI3K)/Akt expression were measured with an NF- $\kappa \mathrm{B}$ enzyme-linked immunosorbent assay kit and western blot analysis, respectively. Eca9706 cells were treated with a PI3K agonist in order to investigate the mechanism of action of psoralidin. It was observed that psoralidin was able to decrease the proliferation and promote the cellular apoptosis of Eca9706 cells in a dose-dependent manner. Furthermore, psoralidin was also able to inhibit the caspase-3 activity of Eca9706 cells in a dose-dependent manner. In addition, psoralidin inhibited NF- $\mathrm{B}$ activity and reduced PI3K and Akt protein expression in Eca9706 cells. Notably, the PI3K agonist was able to reverse the effect of psoralidin on Eca9706 cells. The results of the present study
\end{abstract}

Correspondence to: Mr. Yanhua Xu, Department of Oncology, Jingzhou Central Hospital, 1 Renmin Road, Jingzhou, Hubei 434020, P.R. China

E-mail: yanhuaxuhj@163.com

${ }^{*}$ Contributed equally

Key words: esophageal cancer, psoralidin, NF-кB, PI3K, Akt demonstrated that psoralidin was able to inhibit proliferation and enhance apoptosis of human esophageal carcinoma cells via the $\mathrm{NF}-\kappa \mathrm{B}$ and $\mathrm{PI} 3 \mathrm{~K} / \mathrm{Akt}$ signaling pathways.

\section{Introduction}

Esophageal cancer is the most common gastrointestinal cancer, and is ranked sixth in terms of worldwide cancer-associated mortality rate (1). According to the World Health Organization histological classification, esophageal cancer includes squamous cell carcinoma (SCC) and adenocarcinoma of the esophagus, which account for 90 and 5\% of cases, respectively (2). The remaining $5 \%$ of cases are rare types of esophageal cancer, including epidermal mucinous carcinoma, small cell carcinoma, leiomyosarcoma and others (3). In the past recent years, the incidence of esophageal adenocarcinoma in the United States and Europe has increased significantly (4). The majority of esophageal cancer cases are SCC, which is ranked fourth in terms of cancer-associated mortality, and the current average annual incidence rate of SCC is $17 / 100,000$ patients $(5,6)$. The male incidence rate of SCC is generally higher, compared with that of females (7). However, there are large differences between different regions, and China is known to be an 'esophageal cancer-prone region' (8).

As an important nuclear transcription factor, nuclear factor $(\mathrm{NF})-\kappa \mathrm{B}$ is able to mediate environmental stimuli, and exerts numerous biological functions via control of gene transcription, including regulation of cell proliferation and apoptosis-mediated immunity, inflammation and tumor formation (9). Han et al (10) indicated that neuregulin 1 was able to promote the progression of gastric cancer via $\mathrm{NF}-\kappa \mathrm{B}$ inactivation. In addition, Dai et al (11) demonstrated that Golgi phosphoprotein 3 was able to promote hepatocellular carcinoma cell aggressiveness via the $\mathrm{NF}-\kappa \mathrm{B}$ signaling pathway. Wang et al (12) reported that andrographolide was able to induce apoptosis of esophageal cancer cells via suppression of the $\mathrm{NF}-\kappa \mathrm{B}$ signaling pathway.

Abnormal apoptosis is directly associated with the occurrence and development of a number of diseases, including cancer, viral diseases and a variety of degenerative diseases (13). Previous studies have revealed that constitutively activated phosphatidylinositol 3-kinase (PI3K)/Akt signaling 
may lead to the development of disorders classified within the human tumor spectrum, including ovarian, breast, endometrial and nasopharyngeal cancer, as well as glioblastoma, medulloblastoma and myeloproliferative abnormal syndrome (14). Furthermore, Wang et al (15) reported that hypomethylation of the catalytic subunit alpha of PI3K has a significant role in the activation of the PI3K/Akt signaling pathway in esophageal cancer. Li et al (16) demonstrated that inhibitor of DNA binding 1, dominant negative helix-loop-helix protein promoted metastasis of human esophageal cancer cells via activation of the PI3K/Akt signaling pathway.

Previous studies have identified that psoralidin contains a variety of compounds, including coumarin, flavonoids, monoterpenes and phenols, which may have immunomodulatory, anti-inflammatory, antioxidant and antitumor effects (17-19). Yang et al (17) reported that psoralidin inhibited the proliferation of androgen-independent prostate cancer cells via PI3K-mediated Akt signaling. Furthermore, Hao et al (20) reported that psoralidin was able to inhibit the proliferation of human lung cancer A549 cells. The present study aimed to provide the first evidence of the anticancer effect of psoralidin on esophageal cancer, and render mechanistic insights into the antitumor action of this compound against human esophageal carcinoma Eca9706 cells.

\section{Materials and methods}

Reagents. Psoralidin (purity, $\geq 98 \%$ ), the chemical structure of which is shown in Fig. 1, was purchased from Sigma-Aldrich (St. Louis, MO, USA). 4',6-diamidino-2-phenylindole (DAPI) was also obtained from Sigma-Aldrich. RPMI-1640 was obtained from Nanjing KeyGen Biotech Co., Ltd. (Nanjing, China). Fetal bovine serum (FBS) was obtained from HyClone (GE Healthcare Life Sciences, Logan, UT, USA). 3-(4,5-dimethylthiazol-2-yl)-2,5-diphenyltetrazolium bromide (MTT) was purchased from Sangon Biotech Co., Ltd. (Shanghai, China). Annexin V-fluorescein isothiocyanate (FITC)/propidium iodide (PI) apoptosis detection kit was obtained from BestBio Biotechnology Co., Ltd. (Shanghai, China). Caspase-3 colorimetric assay kit and $\mathrm{NF}-\kappa \mathrm{B}$ enzyme-linked immunosorbent assay (ELISA) kit were acquired from Beyotime Institute of Biotechnology (Nanjing, China).

Cell culture. The Eca9706 human esophageal carcinoma cell line was acquired from the Department of Oncology of Jingzhou Central Hospital (Jingzhou, China). Cells were cultured in RPMI-1640 medium supplemented with $10 \%$ (v/v) FBS, $100 \mathrm{U} / \mathrm{ml}$ penicillin (Invitrogen; Thermo Fisher Scientific, Inc., Waltham, MA, USA) and $100 \mathrm{mg} / \mathrm{ml}$ streptomycin (Invitrogen; Thermo Fisher Scientific, Inc.), at $37^{\circ} \mathrm{C}$ in a humidified atmosphere of $5 \% \mathrm{CO}_{2}$. The culture medium was replaced every 2-3 days, and fresh complete medium was added to cells.

MTT assay. The viability of Eca9706 cells (2.0x10 cells/well) was investigated following incubation with psoralidin $(0,5$, 10 and $20 \mu \mathrm{M})$. Cells were incubated at $37^{\circ} \mathrm{C}$ in a humidified atmosphere of $5 \% \mathrm{CO}_{2}$ for $0,1,2$ and 3 days in 96-well plates (Thermo Fisher Scientific). Eca9706 cells were washed twice using phosphate-buffered saline (PBS; Sangon Biotech Co.,

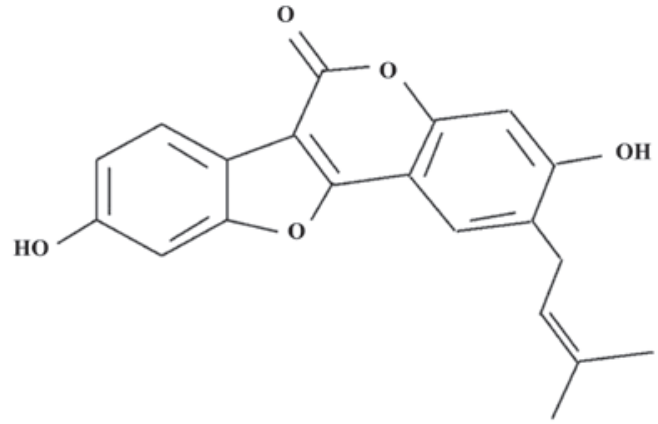

Figure 1. Chemical structure of psoralidin.

Ltd.), and $10 \mu \mathrm{l}$ MTT was added to each well. Subsequently, Eca9706 cells were incubated at $37^{\circ} \mathrm{C}$ in a humidified atmosphere of $5 \% \mathrm{CO}_{2}$ for $4 \mathrm{~h}$. Following incubation, the culture medium was removed, and $150 \mu \mathrm{l}$ dimethyl sulfoxide (Invitrogen; Thermo Fisher Scientific, Inc.) was added into each well. Eca9706 cells were incubated for $20 \mathrm{~min}$ at room temperature. The absorbance of Eca9706 cells at $570 \mathrm{~nm}$ (iMark microplate reader; Bio-Rad Laboratories, Inc., Hercules, CA, USA) was determined by MTT assay, as previously described (21).

Flow cytometric detection of cellular apoptosis. Eca9706 cells $\left(2 \times 10^{6}\right.$ cells/well) were cultured in 6-well plates (Thermo Fisher Scientific) with psoralidin $(0,5,10$ and $20 \mu \mathrm{M})$ at $37^{\circ} \mathrm{C}$ in a humidified atmosphere of $5 \% \mathrm{CO}_{2}$ for 2 days. Following incubation, Eca9706 cells were collected and washed twice with cold PBS. Subsequently, annexin V binding buffer was used to resuspend Eca9706 cells $\left(1 \times 10^{6}\right.$ cells $\left./ \mathrm{ml}\right)$ in a test tube. A total of $10 \mu \mathrm{l}$ annexin V-FITC was added to the resuspended Eca9706 cells, and incubated for $30 \mathrm{~min}$ in the dark. Following incubation, $5 \mu \mathrm{l}$ PI was added to the resuspended Eca9706 cells, and incubated for $10 \mathrm{~min}$ in the dark. Apoptosis of Eca9706 cells was immediately measured using flow cytometry (COULTER ${ }^{\circledR}$ EPICS $^{\circledR}$ ALTRA $^{\mathrm{TM}}$ Flow Cytometer; Beckman Coulter, Inc., Brea, CA, USA).

DAPI staining assay. Eca9706 cells $\left(2 \times 10^{6}\right.$ cells/well) were cultured in 6-well plates with psoralidin $(0,5,10$ and $20 \mu \mathrm{M})$, at $37^{\circ} \mathrm{C}$ in a humidified atmosphere of $5 \% \mathrm{CO}_{2}$ for 2 days. PBS was used to wash the cells, prior to the addition of $0.5 \mathrm{ml} /$ well 4\% paraformaldehyde (Beijing Dingguo Changsheng Biotechnology Co., Ltd., Beijing, China). Cells were fixed for $30 \mathrm{~min}$ at $4^{\circ} \mathrm{C}$, washed twice with $\mathrm{PBS}$, and incubated for $5 \mathrm{~min}$ at $4^{\circ} \mathrm{C}$ in the presence of sodium citrate $(0.1 \%$; Xinfan Biological Technology Co., Ltd., Shanghai, China) containing $0.1 \%$ Triton X-100 (Biosharp, St. Louis, MO, USA). DAPI $(5 \mu \mathrm{g} / \mathrm{ml})$ was added to each well, and incubated for $10-15 \mathrm{~min}$ at $4^{\circ} \mathrm{C}$ in the dark. Eca9706 cells were observed and photographed under a fluorescence microscope (Axio Observer A1; Zeiss AG, Oberkochen, Germany) at excitation/emission $\sim 340 / 450 \mathrm{~nm}$.

Detection of caspase- 3 activity. Eca9706 cells ( $2 \times 10^{6}$ cells/well) were cultured in 6-well plates with psoralidin $(0,5,10$ and $20 \mu \mathrm{M})$ at $37^{\circ} \mathrm{C}$ in a humidified atmosphere of $5 \% \mathrm{CO}_{2}$ for 2 days. Caspase- 3 activity was detected at a wavelength of 405/650 nm (excitation/emission) using a caspase-3 colorimetric assay kit, according to the manufacturer's protocol. 


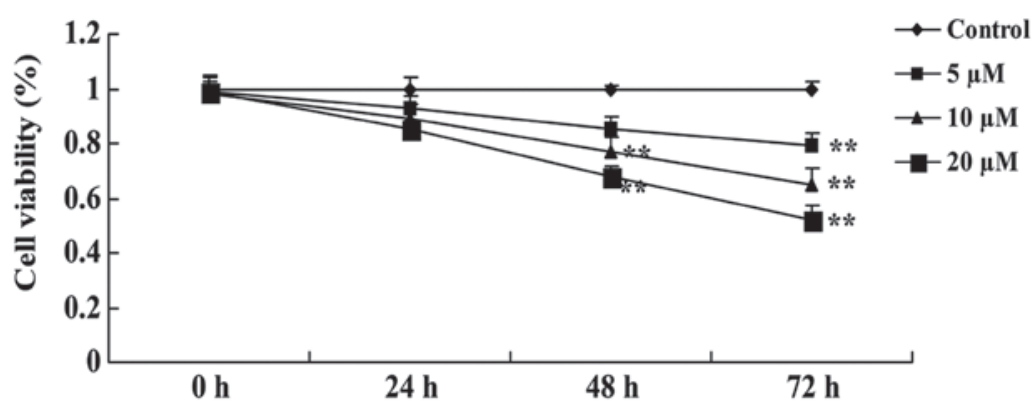

Figure 2. Psoralidin inhibits the viability of Eca9706 cells. Data are expressed as the mean \pm standard deviation of $\geq 3$ independent experiments. ${ }^{* *} \mathrm{P}<0.01$ vs. control group.

MeasurementofNF- $\kappa$ Bactivity.Eca9706 cells $\left(2 \times 10^{6}\right.$ cells/well) were cultured in 6-well plates with psoralidin $(0,5,10$ and $20 \mu \mathrm{M})$ at $37^{\circ} \mathrm{C}$ in a humidified atmosphere of $5 \% \mathrm{CO}_{2}$ for 2 days. NF- $\kappa \mathrm{B}$ activity was analyzed using an ELISA kit, according to the manufacturer's protocol.

Western blot analysis. Eca9706 cells $\left(2 \times 10^{6}\right.$ cells/well) were cultured in 6-well plates with psoralidin $(0,5,10$ and $20 \mu \mathrm{M})$ at $37^{\circ} \mathrm{C}$ in a humidified atmosphere of $5 \% \mathrm{CO}_{2}$ for 2 days. Subsequently, Eca9706 cells were incubated on ice for 30 min with ice-cold lysis buffer (Biosharp), and centrifuged at $12,000 \mathrm{x} \mathrm{g}$ (Biosharp) for $10 \mathrm{~min}$ at $4^{\circ} \mathrm{C}$. The supernatant was collected in order to determine the total protein concentration using Pierce BCA Protein Assay Kit (Thermo Fisher Scientific, Inc.). Equivalent amounts of total protein were separated by $12 \%$ sodium dodecyl sulfate-polyacrylamide gel electrophoresis (Tiandz, Inc., Beijing, China) and subsequently transferred onto a polyvinylidene difluoride membrane (pore size, $0.22 \mu \mathrm{m}$; Roche Diagnostics $\mathrm{GmbH}$, Mannheim, Germany). The membrane was blocked with Tris-buffered saline (TBS; Tiandz, Inc.) containing 5\% skimmed milk for $2 \mathrm{~h}$ at room temperature, and subsequently incubated overnight at $4{ }^{\circ} \mathrm{C}$ with goat polyclonl anti-PI3K (catalog no., sc-48637; dilution, 1:2,000; Santa Cruz Biotechnology, Inc., Dallas, TX, USA), mouse monoclonal anti-Akt (catalog no., sc-293125; dilution, 1:2,500; Santa Cruz Biotechnology, Inc.) or mouse monclonal anti- $\beta$-actin (catalog no., sc-8432; dilution, 1:500; Santa Cruz Biotechnology, Inc.; control) antibodies. The membrane was washed twice using TBS and $0.05 \%$ Tween 20 (Biosharp) for $2 \mathrm{~h}$, and subsequently incubated at room temperature for $2 \mathrm{~h}$ with horseradish peroxidase-conjugated rabbit anti-mouse immunoglobulin G (catalog no., sc-358922; dilution, 1:1,000; Santa Cruz Biotechnology, Inc.). The specific protein bands were detected using enhanced chemiluminescence (Beyotime Institute of Biotechnology), FluorChem ${ }^{\mathrm{TM}}$ (ProteinSimple, Santa Clara, CA, USA) and AlphaEaseFC ${ }^{\text {тм }}$ software (Alpha Innotech, San Leandro, CA, USA).

Statistical analysis. Statistical analysis was performed with SPSS version 17.0 (SPSS Inc., Chicago, IL, USA). Data are expressed as the mean \pm standard deviation of $\geq 3$ independent experiments. Data was analyzed using the Student's t-test. $\mathrm{P}<0.05$ was considered to indicate a statistically significant difference.

\section{Results}

Psoralidin inhibits the viability of Eca9706 cells. In order to clarify the anticancer effect of psoralidin $(0,5,10$ and $20 \mu \mathrm{M})$ on the viability of Eca9706 cells, cell viability was evaluated using an MTT assay. Treatment with psoralidin (5, 10 and $20 \mu \mathrm{M}$ ) affected the viability of Eca9706 cells in a dose- and time-dependent manner. Notably, the anticancer effect of psoralidin at 10 and $20 \mu \mathrm{M}$ significantly inhibited the proliferation of Eca9706 cells at 48 and $72 \mathrm{~h}$ (Fig. 2). Therefore, 48 -h exposure to $10 \mu \mathrm{M}$ psoralidin was selected as the standard pretreatment in subsequent experiments.

Psoralidin induces apoptosis of Eca9706 cells. In order to reveal the anticancer effect of psoralidin $(0,5,10$ and $20 \mu \mathrm{M}$ ) on the apoptosis of Eca9706 cells, the apoptotic rate of Eca9706 cells exposed to psoralidin was analyzed with flow cytometry and DAPI staining assay. Treatment with psoralidin $(5,10$ and $20 \mu \mathrm{M})$ induced apoptosis of Eca9706 cells in a dose-dependent manner. Notably, the apoptotic rate of Eca9706 cells was significantly increased due to the anticancer effect of psoralidin (10 and $20 \mu \mathrm{M})$ following $48 \mathrm{~h}$ of incubation (Fig. 3A). Furthermore, apoptosis of Eca9706 cells was augmented in psoralidin-treated (5, 10 and $20 \mu \mathrm{M})$ cells, compared with the control group (Fig. 3B).

Psoralidin induces caspase-3 activity in Eca9706 cells. In order to investigate the anticancer effect of psoralidin $(0,5$, 10 and $20 \mu \mathrm{M}$ ) on the caspase-3 activity of Eca9706 cells, caspase-3 activity was measured using a colorimetric assay kit. Treatment with psoralidin $(5,10$ and $20 \mu \mathrm{M})$ induced caspase-3 activity in a dose-dependent manner. Notably, following treatment with psoralidin $(10$ and $20 \mu \mathrm{M})$ for $48 \mathrm{~h}$, caspase-3 activity was significantly augmented (Fig. 4).

Psoralidin inhibits $N F-\kappa B$ activity in Eca9706 cells. In order to investigate the effect on $\mathrm{NF}-\kappa \mathrm{B}$ activity caused by treatment with psoralidin $(0,5,10$ and $20 \mu \mathrm{M})$ in Eca9706 cells, the activity of the p65 subunit of NF- $\mathrm{BB}$ was investigated using an ELISA kit. Treatment with psoralidin (5, 10 and $20 \mu \mathrm{M})$ inhibited the activity of NF- $\kappa \mathrm{B}$ in Eca9706 cells (Fig. 5).

Psoralidin inhibits $P I 3 K$ and Akt protein expression in Eca9706 cells. In order to determine the effect of psoralidin $(0,5,10$ and $20 \mu \mathrm{M})$ on the PI3K/Akt signaling pathway in 

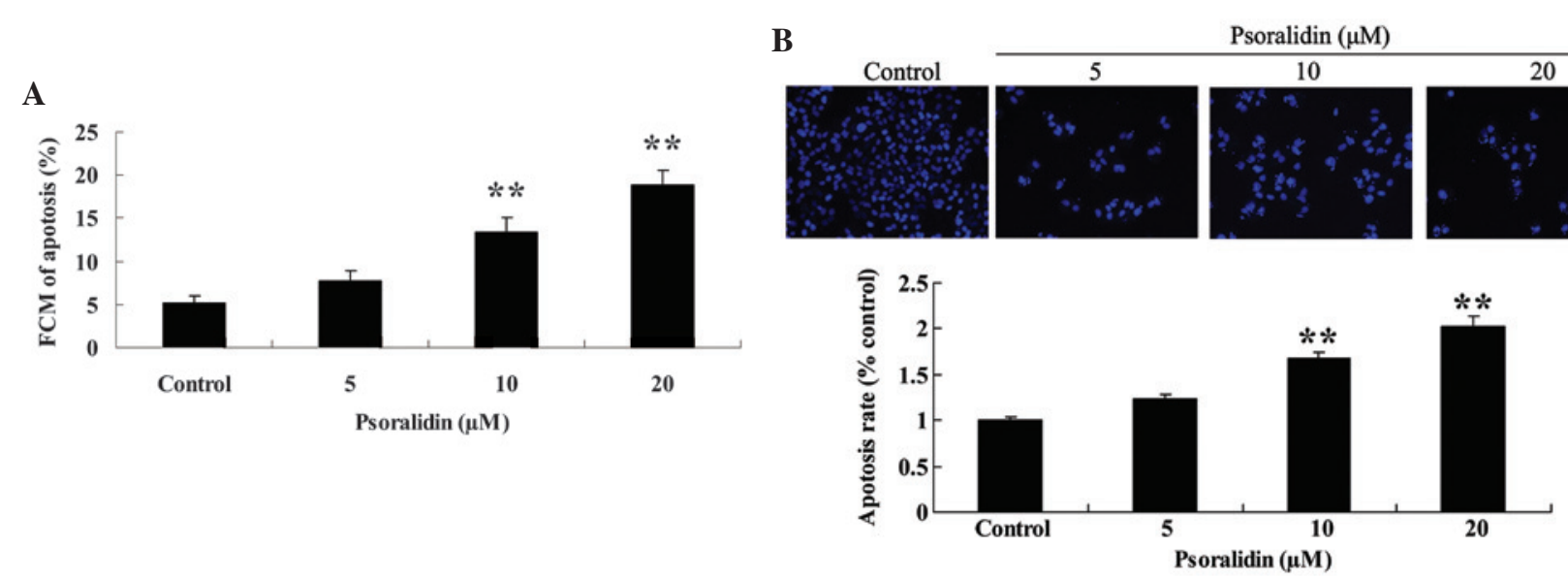

Figure 3. Psoralidin induces apoptosis of Eca9706 cells. The effect of psoralidin treatment on apoptosis of Eca9706 cells was assessed by (A) flow cytometry and (B) 4',6-diamidino-2-phenylindole staining. Data are expressed as the mean \pm standard deviation of $\geq 3$ independent experiments. Magnification, $x 200$. ${ }^{* *} \mathrm{P}<0.01$ vs. control group. FCM, flow cytometry.

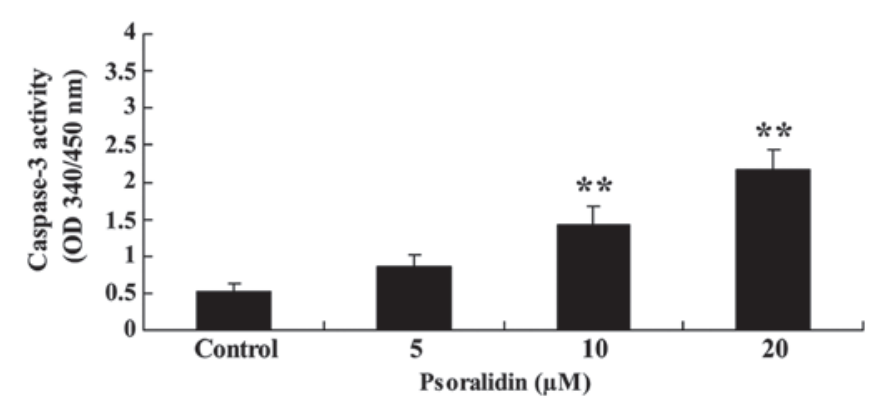

Figure 4. Psoralidin induces caspase-3 activity of Eca9706 cells. Data are expressed as the mean \pm standard deviation of $\geq 3$ independent experiments. ${ }^{* *} \mathrm{P}<0.01$ vs. control group. OD $340 / 450 \mathrm{~nm}$, excitation/emission wavelength.

Eca9706 cells, PI3K and Akt protein expression in Eca9706 cells was detected by western blot analysis. Treatment with psoralidin $(5,10$ and $20 \mu \mathrm{M})$ reduced the protein expression levels of PI3K and Akt in Eca9706 cells (Fig. 6).

PI3K agonist is able to reverse the effect of psoralidin on Eca9706 cells. In order to investigate the potential association between upregulation of $\mathrm{PI} 3 \mathrm{~K}$ protein expression and the effect of psoralidin on Eca9706 cells, Eca9706 cells were incubated with a PI3K agonist, namely insulin-like growth factor $1(1 \mu \mathrm{g} / 10 \mu \mathrm{l})$ for $48 \mathrm{~h}$. Notably, the PI3K agonist markedly increased PI3K protein expression in Eca9706 cells (Fig. 7A and B), and increased the viability of Eca9706 cells (Fig. 7C), compared with the psoralidin-treated (10 $\mu \mathrm{M})$ group.

\section{Discussion}

Esophageal cancer is a common type of human cancer, and is ranked second and third in terms of cancer-associated mortality in men and women, respectively (22). The treatment of esophageal cancer may include surgery, radiation therapy and comprehensive treatment, among which, surgical treatment is preferred (23). However, only $1 / 4$ of patients are able to tolerate radical surgery (24). Radiation therapy is a safe and effective method for the treatment of esophageal cancer (25). As cancer

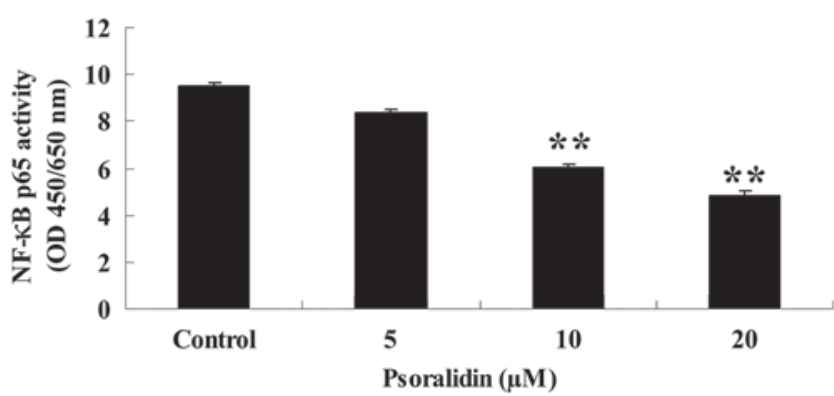

Figure 5. Psoralidin inhibits the activity of the p65 subunit of nuclear factor- $\kappa \mathrm{B}$ in Eca9706 cells. Data are expressed as the mean \pm standard deviation of $\geq 3$ independent experiments. ${ }^{* *} \mathrm{P}<0.01$ vs. control group. OD 450/650 nm, excitation/emission wavelength. $\mathrm{NF}-\kappa \mathrm{B}$, nuclear factor- $\kappa \mathrm{B}$; OD, optical density.

possesses the characteristics of recurrence and metastasis, a review of the efficacy of radiation therapy for patients with esophageal cancer prior to discharge from hospital is important for consolidation and reduction of the recurrence rate (26). In the present study, the anticancer effect of psoralidin resulted in significant inhibition of cell proliferation and increased apoptosis of Eca9706 cells in a dose-dependent manner. Furthermore, psoralidin was additionally able to decrease the caspase-3 activity of Eca9706 cells in a dose-dependent manner. Hao et al (20) reported that psoralidin was able to inhibit the proliferation of A549 human lung cancer cells via generation of reactive oxygen species. Yang et al (17) reported that psoralidin was able to inhibit cell viability and induce apoptosis in human prostate cancer PC-3 and DU-145 cells. Das et al (27) suggested that psoralidin promoted growth arrest via activation of caspase- 3 and caspase- 9 in prostate cancer cells.

Loss of control of $\mathrm{NF}-\kappa \mathrm{B}$ activity is associated with the occurrence of mammalian tumors (28). Activation and abnormal expression of $\mathrm{NF}-\kappa \mathrm{B}$ is observed in numerous tumors (29). In esophageal cancer tissue, $\mathrm{NF}-\kappa \mathrm{B}$ gene amplification is common in the form of multiple internal and external factors acting on the body, which encode proteins that are expressed in the cytoplasm and nucleus (30). A number of intracellular signal transduction pathways are activated, and 
A

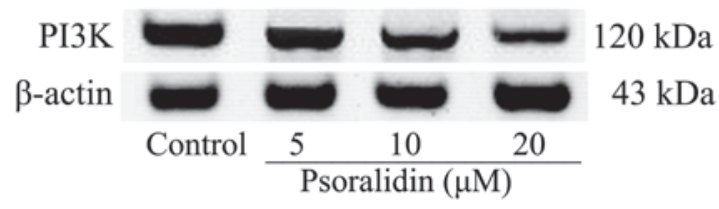

C

Akt

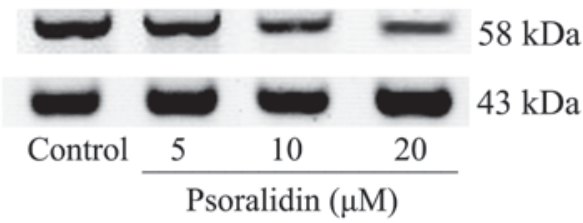

B

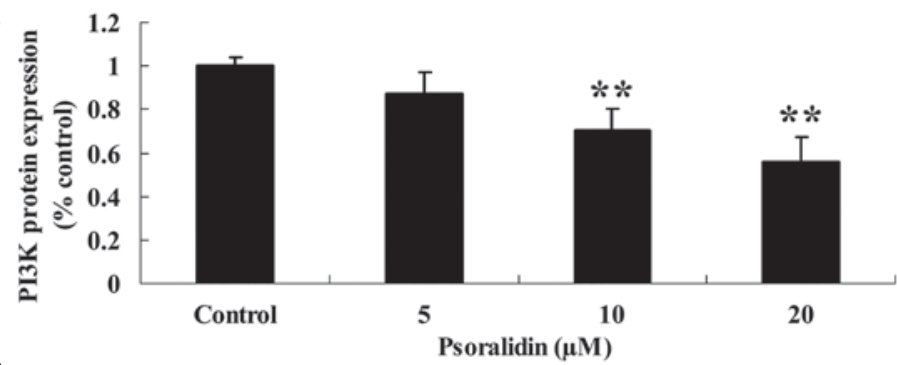

D

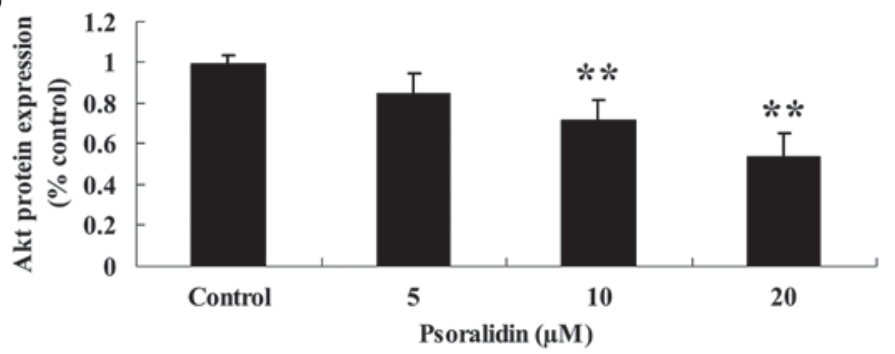

Figure 6. Effect of psoralidin treatment on PI3K and Akt protein expression in Eca9706 cells. (A) The effect of psoralidin on PI3K protein expression in Eca9706 cells was assessed by western blotting. (B) Statistical analysis of PI3K protein expression in Eca9706 cells. (C) The effect of psoralidin on Akt protein expression in Eca9706 cells was assessed by western blotting. (D) Statistical analysis of Akt protein expression in Eca9706 cells. Data are expressed as the mean \pm standard deviation of $\geq 3$ independent experiments. ${ }^{* *} \mathrm{P}<0.01$ vs. control group. PI3K, phosphoinositide 3-kinase.

A

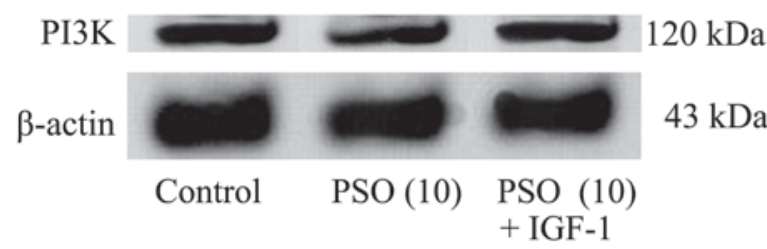

C

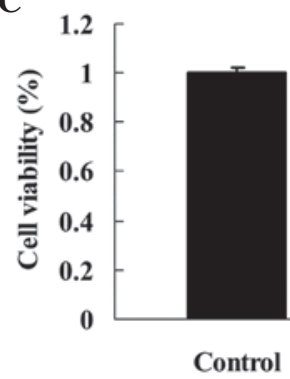

B

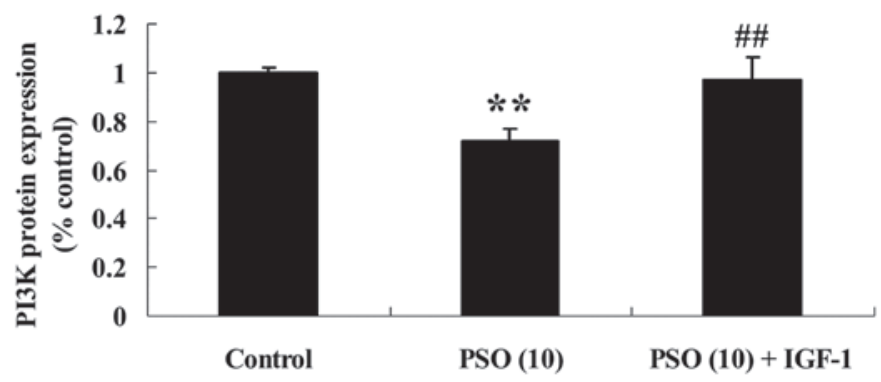

\#\#

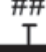

PSO (10) + IGF-1

Figure 7. IGF-1, a PI3K agonist, is able to reverse the effects of psoralidin on Eca9706 cells. (A) The effects of IGF-1 on PI3K protein expression in Eca9706 cells were assessed by western blotting. (B) Statistical analysis of PI3K protein expression in Eca9706 cells. (C) Effects of IGF-1 on the viability of Eca9706 cells. Data are expressed as the mean \pm standard deviation of $\geq 3$ independent experiments. ${ }^{* *} \mathrm{P}<0.01$ vs. control group; ${ }^{\# \#} \mathrm{P}<0.01$ vs. PSO (10) group. PI3K, phosphoinositide 3-kinase; PSO (10), psoralidin (10 $\mu \mathrm{M})$; IGF-1, insulin-like growth factor 1.

malignant cells abnormally proliferate, eventually leading to cancer (31). The present study demonstrated that treatment with psoralidin inhibited the NF- $\kappa$ B activity of Eca9706 cells. Chiou et al (32) reported that psoralidin inhibited lipopolysaccharide-induced expression of nitric oxide via the $\mathrm{NF}-\kappa \mathrm{B}$ signaling pathway. Yang et al (17) suggested that psoralidin regulated ionizing radiation-induced pulmonary inflammation via modulation of the $\mathrm{NF}-\kappa \mathrm{B}$ signaling pathway.

Previous studies have demonstrated that the PI3K/Akt signaling pathway has a significant role in the development of a number of tumors (33). PI3K/Akt signaling primarily exerts anti-apoptotic effects by affecting multiple downstream effector molecules (34). Knockout of PI3K, Akt and associated genes by genetic intervention, or inhibition by small molecule drugs, which blocks the activation of downstream anti-apoptotic effector molecules and promotes apoptosis, has become a key focus of research on cancer treatment (35). The results of the present study suggested that psoralidin was able to reduce the protein expression levels of PI3K and Akt in Eca9706 cells; however, upregulation of PI3K protein expression reduced the viability of Eca9706 cells. Previous studies have demonstrated that psoralidin is able to regulate ionizing radiation-induced pulmonary inflammation via regulation of the PI3K/Akt signaling pathway (17), and is 
also capable of inhibiting lipopolysaccharide-induced nitric oxide expression via the activation of PI3K/Akt-mediated signaling (32).

In conclusion, the results of the present study suggested that psoralidin may have significant therapeutic effects on esophageal cancer, via the $\mathrm{NF}-\kappa \mathrm{B}$ and PI3K/Akt signaling pathways. The results of the present study additionally suggest the potential benefits of the use of psoralidin in clinical practice.

\section{References}

1. He B, Yin B, Wang B, Xia Z, Chen C and Tang J: MicroRNAs in esophageal cancer (Review). Mol Med Rep 6: 459-465, 2012.

2. Yano T, Muto M, Yoshimura K, Niimi M, Ezoe Y, Yoda Y, Yamamoto Y, Nishisaki H, Higashino K and Iishi H: Phase I study of photodynamic therapy using talaporfin sodium and diode laser for local failure after chemoradiotherapy for esophageal cancer. Radiat Oncol 7: 113, 2012.

3. Kano Y, Konno M, Ohta K, Haraguchi N, Nishikawa S, Kagawa Y, Hamabe A, Hasegawa S, Ogawa H, Fukusumi T, et al: Jumonji/Arid1b (Jarid1b) protein modulates human esophageal cancer cell growth. Mol Clin Oncol 1: 753-757, 2013.

4. Su S, Scott WJ, Allen MS, Darling GE, Decker PA, McKenna RJ and Meyers BF: Patterns of survival and recurrence after surgical treatment of early stage non-small cell lung carcinoma in the ACOSOG Z0030 (ALLIANCE) trial. J Thorac Cardiovasc Surg 147: 747-752, discussion 752-753, 2014.

5. Furusaka T, Matsuda A, Tanaka A, Matsuda H and Ikeda M: Superselective intra-arterial chemoradiation therapy for functional laryngeal preservation in advanced squamous cell carcinoma of the glottic larynx. Acta Otolaryngol 133: 633-640, 2013.

6. Chak A, Buttar NS, Foster NR, Seisler DK, Marcon NE, Schoen R, Cruz-Correa MR, Falk GW, Sharma P, Hur C, et al: Metformin does not reduce markers of cell proliferation in esophageal tissues of patients with Barrett's esophagus. Clin Gastroenterol Hepatol 13: 665-672, e661-664, 2015.

7. Huang YC, Chang PM, Chen MH, Chu PY, Tzeng $\mathrm{CH}$ Chang SY and Yang MH: A study using ifosfamide and etoposide in patients with cisplatin - refractory recurrent or metastatic head and neck squamous cell carcinoma. Jpn J Clin Oncol 41: 630-636, 2011

8. Takeno S, Yamashita SI, Yamamoto S, Takahashi Y, Moroga T, Kawahara K, Shiroshita T, Yamana I, Maki K and Yamashita Y: Number of metastasis-positive lymph node stations is a simple and reliable prognostic factor following surgery in patients with esophageal cancer. Exp Ther Med 4: 1087-1091, 2012.

9. Yang JJ, Li WH, Liu BJ, Tang RH and Zhang YH: Influence of pentylenetetrazol and $\mathrm{NF}-\kappa \mathrm{B}$ decoy oligodeoxynucleotides on p38 expression in neuron-like cells. Exp Ther Med 8: 395-400, 2014.

10. Han ME, Kim HJ, Shin DH, Hwang SH, Kang CD and Oh SO: Overexpression of NRG1 promotes progression of gastric cancer by regulating the self-renewal of cancer stem cells. J Gastroenterol 50: 645-656, 2015.

11. Dai T, Zhang D, Cai M, Wang C, Wu Z, Ying Z, Wu J, Li M, Xie D, Li J and Song L: Golgi phosphoprotein 3 (GOLPH3) promotes hepatocellular carcinoma cell aggressiveness by activating NF- $\kappa$ B pathway. J Pathol 235: 490-501, 2015.

12. Wang ZM, Kang YH, Yang X, Wang JF, Zhang Q, Yang BX, Zhao KL, Xu LP, Yang LP, Ma JX, et al: Andrographolide radiosensitizes human esophageal cancer cell line ECA109 to radiation in vitro. Dis Esophagus: Jul 25, 2014 (Epub ahead of print).

13. Yang B, Rice TW, Adelstein DJ, Rybicki LA and Goldblum JR: Overexpression of $\mathrm{p} 53$ protein associates decreased response to chemoradiotherapy in patients with esophageal carcinoma. Mod Pathol 12: 251-256, 1999.

14. Yang Y, Hui L, Yuqin C, Jie L, Shuai H, Tiezhu Z and Wei W: Effect of saw palmetto extract on PI3K cell signaling transduction in human glioma. Exp Ther Med 8: 563-566, 2014.

15. Wang WF, Xie Y, Zhou ZH, Qin ZH, Wu JC and He JK: PIK3CA hypomethylation plays a key role in activation of the $\mathrm{PI} 3 \mathrm{~K} / \mathrm{AKT}$ pathway in esophageal cancer in Chinese patients. Acta Pharmacol Sin 34: 1560-1567, 2013.
16. Li B, Tsao SW, Li YY, Wang X, Ling MT, Wong YC, He QY and Cheung AL: Id-1 promotes tumorigenicity and metastasis of human esophageal cancer cells through activation of PI3K/AKT signaling pathway. Int J Cancer 125: 2576-2585, 2009

17. Yang HJ, Youn H, Seong KM, Yun YJ, Kim W, Kim YH, Lee JY, Kim CS, Jin YW and Youn B: Psoralidin, a dual inhibitor of COX-2 and 5-LOX, regulates ionizing radiation (IR)-induced pulmonary inflammation. Biochem Pharmacol 82: 524-534, 2011.

18. Yi LT, Li YC, Pan Y, Li JM, Xu Q, Mo SF, Qiao CF, Jiang FX, Xu HX, Lu XB, et al: Antidepressant-like effects of psoralidin isolated from the seeds of Psoralea corylifolia in the forced swimming test in mice. Prog Neuropsychopharmacol Biol Psychiatry 32: 510-519, 2008.

19. Xiao G, Li G, Chen L, Zhang Z, Yin JJ, Wu T, Cheng Z, Wei X and Wang Z: Isolation of antioxidants from Psoralea corylifolia fruits using high-speed counter-current chromatography guided by thin layer chromatography-antioxidant autographic assay. J Chromatogr A 1217: 5470-5476, 2010.

20. Hao W, Zhang X, Zhao W and Chen X: Psoralidin induces autophagy through ROS generation which inhibits the proliferation of human lung cancer A549 cells. PeerJ 2: e555, 2014.

21. Pu Z, Zhang X, Chen Q, Yuan X and Xie H: Establishment of an expression platform of OATP1B1 388GG and 521CC genetic polymorphism and the therapeutic effect of tamoxifen in MCF-7 cells. Oncol Rep 33: 2420-2428, 2015.

22. Wang S, Liu H, Wang Z and Chen HX: Effects of 5-azacytidine on RUNX3 gene expression and the biological behavior of esophageal carcinoma cells. Mol Med Rep 9: 1259-1265, 2014.

23. Kataoka K, Nakamura K, Mizusawa J, Fukuda H, Igaki H, Ozawa S, Hayashi K, Kato K, Kitagawa Y and Ando N: Variations in survival and perioperative complications between hospitals based on data from two phase III clinical trials for oesophageal cancer. Br J Surg 102: 1088-1096, 2015.

24. Shiozaki A, Fujiwara H, Konishi H, Morimura R, Komatsu S, Murayama Y, Kuriu Y, Ikoma $\mathrm{H}$, Kubota T, Nakanishi M, et al: Middle and lower esophagectomy preceded by hand-assisted laparoscopic transhiatal approach for distal esophageal cancer. Mol Clin Oncol 2: 31-37, 2014.

25. Yu L, Ge X, Huang S, Wang Y and Shen P: Primary squamous cell carcinoma of the esophagus initially presenting as a large retroperitoneal mass: A case diagnosed as cancer of unknown primary site. Mol Clin Oncol 1: 503-506, 2013.

26. Chen H, Wang Z, Yang Z, Shang B, Liu X and Chen G: Prospective study of adjuvant radiotherapy on preventing lymph node metastasis after Ivor-lewis esophagectomy in esophageal cancer. Ann Surg Oncol 20: 2721-2726, 2013.

27. Das TP, Suman S and Damodaran C: Induction of reactive oxygen species generation inhibits epithelial-mesenchymal transition and promotes growth arrest in prostate cancer cells. Mol Carcinog 53: 537-547, 2014

28. Cras A, Politis B, Balitrand N, Darsin-Bettinger D, Boelle PY, Cassinat $\mathrm{B}$, Toubert ME and Chomienne $\mathrm{C}$ : Bexarotene via $\mathrm{CBP} / \mathrm{p} 300$ induces suppression of NF- $\mathrm{KB}$-dependent cell growth and invasion in thyroid cancer. Clin Cancer Res 18: 442-453, 2012.

29. Rengarajan T, Nandakumar N, Rajendran P, Haribabu L, Nishigaki I and Balasubramanian MP: D-pinitol promotes apoptosis in MCF-7 cells via induction of p53 and Bax and inhibition of Bcl-2 and NF- $\mathrm{KB}$. Asian Pac J Cancer Prev 15: 1757-1762, 2014

30. Hasan R, Chauhan SS, Sharma R and Ralhan R: siRNA-mediated downregulation of TC21 sensitizes esophageal cancer cells to cisplatin. World J Gastroenterol 18: 4127-4135, 2012.

31. Yoon JH, Cho ML, Choi YJ, Back JY, Park MK, Lee SW, Choi BJ, Ashktorab H, Smoot DT, Nam SW, et al: Gastrokine 1 regulates $\mathrm{NF}-\mathrm{kB}$ signaling pathway and cytokine expression in gastric cancers. J Cell Biochem 114: 1800-1809, 2013.

32. Chiou WF, Don MJ, Liao JF and Wei BL: Psoralidin inhibits LPS-induced iNOS expression via repressing Syk-mediated activation of PI3K-IKK-I $\mathrm{B}$ signaling pathways. Eur J Pharmacol 650: 102-109, 2011.

33. Wheler JJ, Moulder SL, Naing A, Janku F, Piha-Paul SA, Falchook GS, Zinner R, Tsimberidou AM, Fu S, Hong DS, et al: Anastrozole and everolimus in advanced gynecologic and breast malignancies: Activity and molecular alterations in the PI3K/AKT/mTOR pathway. Oncotarget 5: 3029-3038, 2014.

34. Pang XL, He G, Liu YB, Wang Y and Zhang B: Endoplasmic reticulum stress sensitizes human esophageal cancer cell to radiation. World J Gastroenterol 19: 1736-1748, 2013.

35. Huang Y and Li LP: Progress of cancer research on astrocyte elevated gene-1/Metadherin (Review). Oncol Lett 8: 493-501, 2014. 